\title{
Long-term stability of the human gut microbiota in two different rat strains
}

\author{
Carl Alpert ${ }^{\text {a, }}{ }^{*}$, Silke Sczesny ${ }^{\text {a, } 1}$, Bärbel Gruhl ${ }^{\text {a }}$, \\ Michael Blaut ${ }^{\text {a }}$ \\ a Department of Gastrointestinal Microbiology, German \\ Institute of Human Nutrition Potsdam-Rehbrücke, Arthur- \\ Scheunert-Allee 114-116, 14558 Nuthetal, Germany \\ 1 present address: Intervet Innovation $\mathrm{GmbH}$, Zur \\ Propstei, 55270 Schwabenheim, Germany
}

\begin{abstract}
Human microbiota associated rats are frequently used as a model to study host microbe interactions. This study investigated the long-term stability of the bacterial community in such rats. Following the association of two strains of germ-free rats (12 male animals each) with fecal bacteria from a human donor the development of the microbiota was monitored for 12 months by PCRdenaturing gradient gel electrophoresis. During this time the Dice similarity coefficient $\left(\mathrm{C}_{\mathrm{s}}\right)$ for the fecal microbial community of the rats associated with a human microbiota in comparison to the donor sample ranged between $73 \% \pm 8$ and $74 \% \pm 3$ for the Wistar and the Fischer 344 rats, respectively. After 12 months the similarity coefficients were $78 \% \pm 9$ and $76 \% \pm 7$, respectively, while the similarity coefficients for rat sample replicates ranged from $77 \% \pm 7$ to $88 \% \pm 5$; the similarity coefficient of the donor sample replicates was $78 \% \pm 9$. DNA sequences of bands observed in the different denaturing gradient gel electrophoresis profiles exhibited the highest degree of identity to uncultured bacteria previously found in samples of human, mouse or pig intestinal origin. The results of this study suggest that the dominant human fecal microbiota can be maintained in the human microbiota associated rat model for at least one year.
\end{abstract}

\section{Introduction}

The microbial community resident in the human colon represents a complex ecosystem, which influences host physiology in many ways. For ethical reasons, host-microbe interactions are difficult to study in humans and investigations have therefore been limited to the analysis of fecal samples. A number of model systems have been used to study various aspects of such interactions. In vitro systems are useful to study bacterial interactions but they ignore host inputs such as gut secretions or immunology (Rumney and Rowland, 1992). Conventional animals are convenient models for investigating the ecology and the microbial metabolism in the gut. However, use of such animals can be questioned because of differences in the composition of the microbiota (Hazenberg et al., 1981) and microbial enzymatic activities (Rowland et al., 1986). In order to evade the problems associated with the use of conventional animals and to retain the advantages of control of diet, environment, genetic background and the composition of the microbiota to be investigated, germfree animals associated with human gut microbiota have been used (Djouzi et al., 1997; Hambly et al., 1997b; Kamlage et al., 1999; Kassie et al., 2001). However, the development and the stability of the intestinal microbiota in such animals have not yet fully been examined. So far, most studies that compared the fecal microbiota of conventional and human microbiota associated (HMA) rodents used conventional microbiological methods to enumerate dominant bacterial groups (Hirayama et al., 1991; Hirayama et al., 1995; Raibaud et al., 1980). In view of the fact that a considerable proportion of intestinal bacteria elude cultivation (Suau et al., 1999), the use of conventional enumeration techniques is insufficient to compare the microbiota of HMA animals and man. To overcome these limitations, some researchers concentrated on the characterization of the metabolic activities of the microbiota (Kassie et al., 2001; Mallett et al., 1987). Others used methods such as dotblot quantification of total RNA extracts with group specific probes (Edwards et al., 2003), whole-cell hybridization with fluorescently labeled $16 \mathrm{~S}$ rRNAtargeted oligonucleotide probes (Gerard et al., 2004) or terminal restriction fragment length polymorphism ( $T$ RFLP) analysis of 16S rRNA gene sequences (Kibe et al., 2005), which permit the culture-independent identification of intestinal bacteria (Vaughan et al., 2000). However, while previous investigations took into account only short examination periods of no more than a few weeks or months, some animal studies related to tumor development were performed for up to half a year (Hambly et al., 1997a; Hambly et al., 1997b), and future models may require even longer trial periods. It is therefore important to ascertain that the composition of a human microbial population can be maintained in the animals for such a long time.

In the present study we investigated the establishment and stability of the microbial community over a 12-month period following the association of two different germ-free rat strains with a complex human fecal microbiota using PCR-denaturing gradient gel electrophoresis (PCR-DGGE). This culture-independent technique allows to follow the development of targeted phylogenetic groups (Satokari et al., 2001) or bacterial populations in complex ecosystems (Muyzer, 1999) without the need to have detailed knowledge about each member of the community. There are some technical shortcomings inherent to this technique such as comigration of different sequences in samples from complex polymicrobial communities (Gafan and Spratt, 2005), PCR bias due to template annealing behavior although this effect is probably less severe in highly complex samples like the fecal microbiota (Suzuki and Giovannoni, 1996) - or detection of different rRNA operons of the same organisms (Nubel et al., 1996), which may influence the banding pattern. However, the obtained community fingerprints for a particular microbiota are reproducible and have been successfully applied to monitoring for example the composition of the predominant bacterial populations in human fecal samples (Zoetendal et al., 1998). Our results indicate that the community structure of the dominant bacterial population groups following their establishment in previously germ-free rats is stable for at least one year and reflects the composition of the donor microbiota at the time of inoculation. 


\section{Results}

Molecular analysis of the human gut microbiota transferred to germ-free rats

Following the association of 12 Wistar and 12 Fischer 344 rats with human fecal microbiota we monitored the development and the stability of the fecal microbiota for periods of three and 12 months, respectively. At the end of the experimental periods the animals were killed and the contents of the cecum were removed. The fecal microbiota composition of the human donor and the rat samples was subsequently analyzed by comparing the corresponding PCR-DGGE profiles.

The reproducibility of the PCR-DGGE method was determined by repeated analyses. The $C_{s}$ values ranged from $77 \% \pm 7$ to $88 \% \pm 5$ for HMA rat samples and reached $78 \% \pm 9$ for repetitions of the human donor sample. To compare the fecal microbiota of the donor with that of conventionalized (CV) rats, fecal samples from six CV rats were also analyzed by PCR-DGGE. The resulting $C_{s}$ ranged from 21 to $42 \%$ (mean $25 \%, p \leq$ 0.05 ), which confirmed the expected difference between the human and rat microbiota.

Development and stability of dominant bacterial population groups in HMA rats in comparison to the human donor sample

The development of the fecal microbiota following the association of germ-free rats with fecal microbiota from a human individual was investigated in detail over a period of three months. One day after the association, in four out of six Wistar rats, most bands in the human DGGE profile were also present in the rat DGGE profiles. The $\mathrm{C}_{\mathrm{s}}$ varied between 34 and $86 \%$. Two days later, the $\mathrm{C}_{\mathrm{s}}$
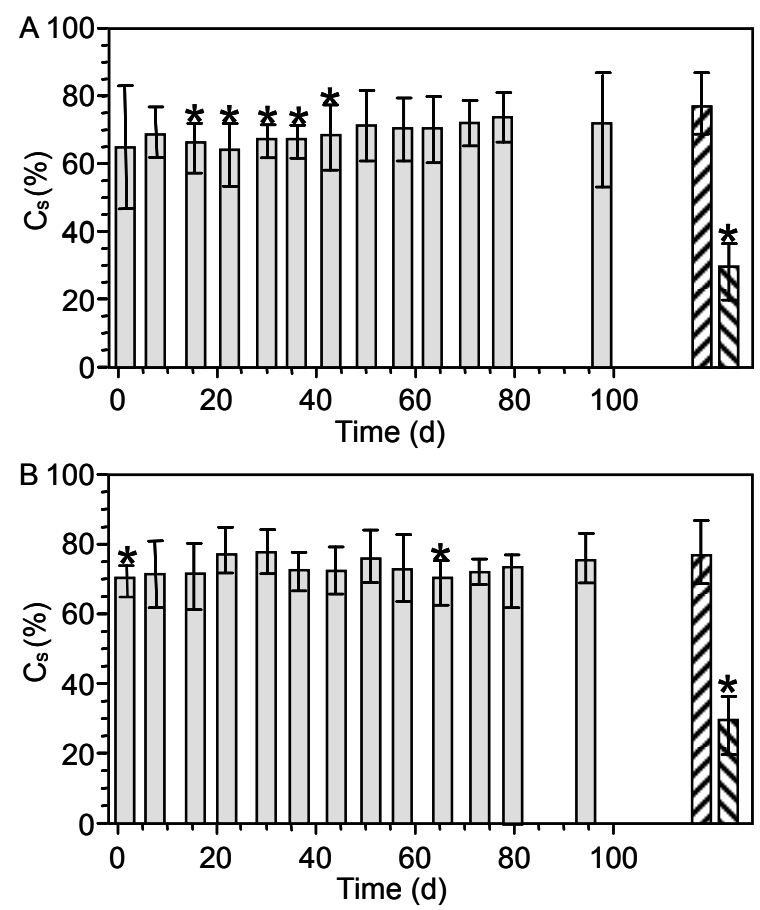

Figure 1: Development of the similarity index $\left(C_{s}\right)$ for the DGGE profiles of HMA rat fecal microbiota determined over a period of three months in comparison to the DGGE profile of the human donor's fecal microbiota. Significant differences between the mean $\mathrm{C}_{\mathrm{s}}$ of each sampling time and the mean $\mathrm{C}_{\mathrm{s}}$ determined for six replications of the human sample are indicated with an asterisk $(p \leq 0.05)$. For reference, the $C_{s}$ of six replications of the human fecal inoculum as well as the $C_{s}$ comparing $C V$ rat samples with the inoculum are also depicted. A: Wistar rats, $B$ : Fischer 344 rats. Error bars indicate the standard deviation (SD). $\square$ HMA rats, $\boldsymbol{Z}$ repetitions of donor sample, $\mathbf{\nabla} \mathrm{CV}$ rats.

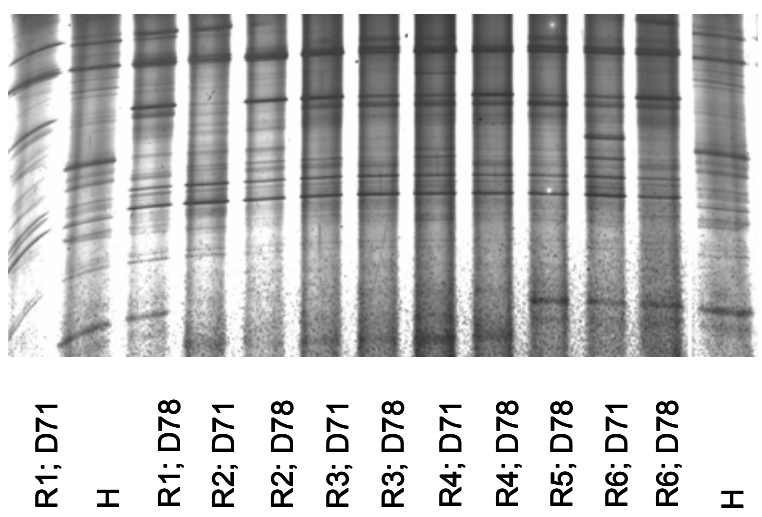

Figure 2: PCR-DGGE profiles representing the predominant bacterial community of human feces $(\mathrm{H})$ and of feces from six HMA Fischer 344 rats (R1 - R6) collected on day 71 (D71) and day 78 (D78) after association.

ranged from 68 to $82 \%$. In the following three months, no major changes could be observed (Fig. 1A). Similarly in Fischer rats, between 67 and $79 \%$ of the bands in DGGE profiles of the rat samples were also found in the DGGE profiles of the human donor sample (Figure 2). This pattern remained relatively stable over three months. This is also reflected by rather small changes in the $\mathrm{C}_{\mathrm{s}}$ during this time (Fig. 1B). Only at a few sampling times did the $\mathrm{C}_{\mathrm{s}}$ of each of the two HMA rat strains differ significantly from the mean $\mathrm{C}_{s}$ resulting from the repeated analysis of the human sample (Figures $1 \mathrm{~A}$ and 1B). Further samples were taken monthly during the 12month experimental period from six additional animals per rat strain (Fig. 3). Starting with day 2 after the association, the $\mathrm{C}_{\mathrm{s}}$ values comparing the human and HMA rat microbiota were $73 \% \pm 8$ and $74 \% \pm 3$ for the Wistar and the Fischer rats, respectively. During the following 12 months no changes in the $C_{s}$ were observed in either rat strain. After 12 months the $C_{s}$ values which compared the human with the Wistar and the Fischer rat samples, were $78 \% \pm 9$ and $76 \% \pm 7$, respectively. No significant differences were observed at any time point of the sampling period (Fig. 3). Although some of the bands differed in their intensity, the DGGE profiles of the human fecal sample on the one hand, and of the HMA rat fecal samples on the other, displayed a high qualitative similarity (Fig. 4).

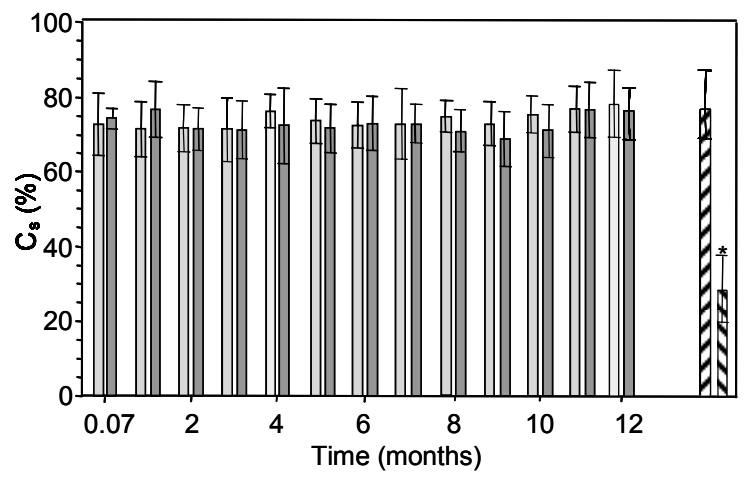

Figure 3: Development of the similarity index $\left(C_{s}\right)$ for the DGGE profiles of HMA Wistar or HMA Fischer 344 rat fecal microbiota determined over a period of 12 months in comparison to the DGGE profile of the human donor's microbiota. Significant differences between the mean $\mathrm{C}_{\mathrm{s}}$ of each sampling time and the mean $\mathrm{C}_{\mathrm{s}}$ estimated for six replicates of the inoculum are indicated with an asterisk $(p \leq 0.05)$. For reference, the $C_{s}$ of six repetitions of the inoculum as well as the $\mathrm{C}_{\mathrm{s}}$ comparing $\mathrm{CV}$ rat samples with the inoculum are also depicted. Error bars indicate the standard deviation (SD). $\square$ HMA Wistar rats, $\square$ HMA Fischer rats, $\square$ repetitions of donor sample, $\mathbf{\nabla} \mathrm{CV}$ rats. 


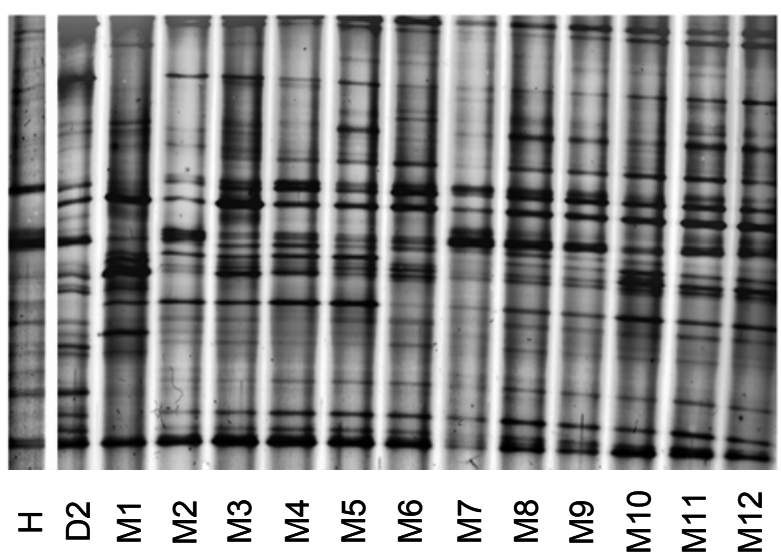

Figure 4: PCR-DGGE profiles representing the predominant community of human feces $(\mathrm{H})$ and of feces from one HMA Wistar rat collected between day 2 (D2) and 12 months (M12) after association.

\section{Microbial diversity of rat cecum contents}

The bacterial community in the rat cecum has a high cell density and is therefore high in microbial enzyme activity. For this reason, the microbial composition of HMA rat cecal microbiota is of special interest in respect to the use of these rats as in vivo models. Therefore, DGGE profiles of the cecal microbiota of HMA rats were compared with fecal microbiota of the human donor. The $\mathrm{C}_{\mathrm{s}}$ values varied from 62 to $80 \%$, which is in the same range as the $C_{s}$ values determined for the comparison of the fecal microbiota of HMA rats and the human donor. A significant difference between the human fecal microbiota and the cecal HMA rat microbiota was only observed in Wistar rats three months after the association (Fig. 5).

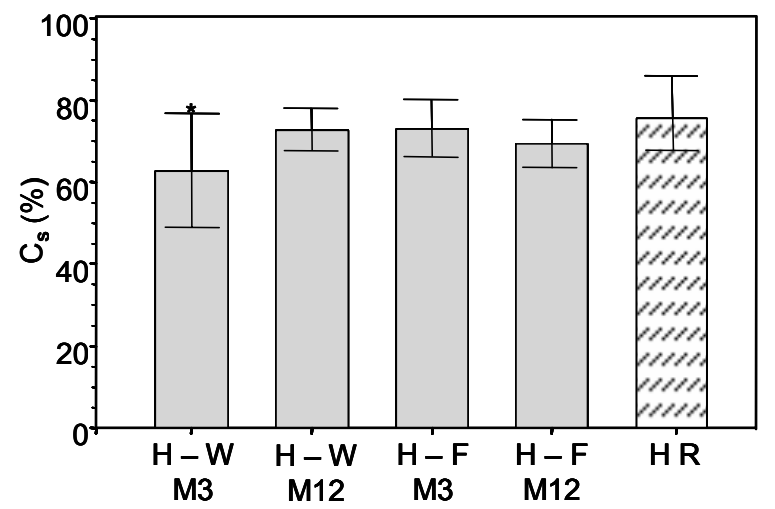

Figure 5: Similarity index $\left(C_{s}\right)$ comparing the DGGE profiles of the cecal microbiota of HMA Wistar (W) or HMA Fischer $344(F)$ rats and the human (H) donor microbiota 3 (M3) and 12 months (M12) after the association of the rats. HR, repetitions of one human donor sample. Significant differences between the mean $C_{s}$ of each sampling time and rat strain and the mean $C_{s}$ estimated for six replicates of one human sample (HR) are indicated with an asterisk $(p \leq 0.05)$. Error bars indicate the standard deviation (SD).

\section{Identification of bands in DGGE profiles}

On several occasions the DGGE profiles of the HMA rats contained bands that were absent from the DGGE pattern of the human donor sample. To get more information on the identity of the organisms underlying these bands, they were excised from the gels, reamplified, and sequenced. Bands in close proximity to other bands in the DGGE gel could not be included in the analysis because they could not be excised as separate bands. Some very fine bands could not be amplified owing to too low amounts of DNA. The sequences derived from five of 31 bands analyzed were identified as chimeras and 13 other bands contained more than one type of sequence and could therefore not be analyzed. The remaining 13 sequences showed similarities of 89 to $96 \%$ to the amplified part of the V6 to V8 region (390 bp) of $16 \mathrm{~S}$ rRNA clones of uncultured bacteria (Table 1), 11 of which were found in human gut or fecal samples, one originated from the pig intestine and one from the mouse intestine. The closest related culturable species belong to the Eubacteriaceae, Enterobacteriaceae, Lachnospiraceae, Clostridiaceae and Clostridiales respectively (Table 1 ).

\section{Discussion}

In the present study we used samples from germ-free male Wistar and Fischer 344 rats associated with human fecal microbiota in order to gain information about the long-term stability of the dominant human gut bacteria in this animal model. The $\mathrm{C}_{s}$ values of the PCR-DGGE patterns of the human donor and the HMA rat fecal microbiota varied between 66 and $89 \%$, whereas the DGGE patterns of the human and CV rat microbiota with a mean $\mathrm{C}_{\mathrm{s}}$ of $25 \%$ differed considerably more. These results extend previous studies performed with conventional microbiological techniques (Hazenberg et al., 1981; Hirayama et al., 1991; Raibaud et al., 1980), which led to the conclusion that predominant cultivable human fecal bacteria can be transferred into rodents with slight modifications of their numbers during a period of five to eight weeks. Our study supports these findings and demonstrates by the use of PCR-DGGE that the transfer of human gut microbiota into germ-free rats causes only minor changes in the dominant microbiota composition during a period of 12 months. In our experiment, the variations in microbial composition showed no trend. Hence, the observed changes are fluctuations in the gut microbiota of individual rats over time. While the data demonstrate that the composition of the dominant bacterial population group in the gut of HMA rats was very similar to that of the human donor sample, the fecal microbiota composition of the $\mathrm{CV}$ rats differed, as would be expected, significantly from that of the human sample. This is in accordance with the findings of Rumney et al. (Rumney et al., 1993).

The PCR-DGGE analysis of the microbiota of the HMA-rat cecum revealed high similarity to the fecal microbiota of the human donor. This finding is in accordance with Mallett et al. (Mallett et al., 1987), who compared the enzymatic profiles of HMA-rat ceca with those of fresh human feces. Using culture methods and quantitative hybridization with a set of six rRNA-targeted probes, Marteau and colleagues detected quantitative rather than qualitative differences in the composition of cecum content and feces of humans (Marteau et al., 2001).

Differences in the DGGE patterns like the loss of a band or the occurrence of new bands may be explained by the association procedure, subject-specific factors involved in the acquisition of the bacterial community (Zoetendal et al., 2001) or differences in nutrition between humans and rats. The same reasons could be responsible for the observed differences in the intensity of some bands, indicating differences in the size of the underlying microbial population groups. To appreciate the meaning of the $C_{s}$ values, it has to be considered that the microbiota of the HMA rats originated from one human individual. The $C_{s}$ value for one individual varies between 65 and $89 \%$ when samples taken at different times are compared, whereas the $C_{s}$ values between 
unrelated persons vary from 31 to $61 \%$ (Zoetendal et al., 2001) and the $C_{s}$ of the gut microbiota among full-term infants is only $11 \%$ (Schwiertz et al., 2003). The $C_{s}$ determined by comparing the DGGE profiles of the fecal microbiota of HMA rats with those of the human donor is in the same range as the $\mathrm{C}_{\mathrm{s}}$ values determined for one individual at different time points, whereas the $C_{s}$ which results from comparing the fecal microbiota of $\mathrm{CV}$ rats and of the donor is below the $C_{s}$ values determined for unrelated human individuals (Zoetendal et al., 2001). Based on the $C_{s}$ values, no significant differences were observed between Fischer or Wistar rats on the one hand and the human donor on the other, indicating that both rat strains can be used for establishing an HMA model.

As already mentioned earlier, PCR-DGGE has the advantage of being a culture-independent method which allows a less biased view of the bacterial community than culture dependent methods. However, the PCRDGGE approach can also lead to some distortions, as some sequences may amplify better than others, and heteroduplexes may be formed during PCR (Wintzingerode et al., 1997). Thus, PCR-DGGE experiments do not reflect the full diversity of the bacterial community under study, but the high degree of reproducibility of the obtained community fingerprints supports the assumption implicit to all PCR-DGGE work that the above mentioned effects will be reproducible as well.

During the analysis of single DGGE bands it became obvious that the extraction of sufficient DNA from each band of interest in the DGGE gel could not always be achieved. Very fine bands did not contain enough DNA template to result in PCR products. Other bands contained non-related sequences that co-migrated. Similar observations have been made for complex matrices (ben Omar and Ampe, 2000). In five cases, sequences showed chimerical characteristics.

The occurrence of such chimeras is not remarkable because the probability of chimera formation rises with a high template concentration and increased species diversity (Qiu et al., 2001).

Those bands, from which DNA could be successfully isolated, amplified and the resulting products sequenced, indicated the presence of bacteria related to as yet uncultured organisms detected previously in samples from human, pig or mouse digestive systems. Since the identity of these partial sequences to sequences of described cultivable species in the database was less than $97 \%$, one can assume that some of these sequences originated from as yet undescribed species (Stackebrandt and Goebel, 1994). These results demonstrate the limitations of previously performed studies, which, owing to the use of conventional techniques (Hazenberg et al., 1981; Hirayama et al., 1991; Raibaud et al., 1980), could not detect changes related to non-cultivable species.

In summary, our results indicate that the predominant bacterial population groups of the fecal microbiota of a human donor could be established and subsequently maintained in ex germ-free rats for at least one year under isolator conditions. Although variations in band intensities were suggestive of quantitative variations of the bacterial population, the most important fact for the HMA rat model is the observation that no major shift in the qualitative composition occurred. It is therefore possible to study the function of the human gut microbiota in vivo on the basis that the bacterial complement with respect to species representation, and consequently enzymatic potential characteristic of the donor, can be stably transferred to the experimental animals.

\section{Materials and Methods}

Animal housing and preparation of fecal samples

Germ-free AVN-Ipcv-Wistar / Rehbruecke $(n=12)$ and germ-free Fischer 344 / Rehbruecke rats $(n=12)$ were used for the experiments. They were obtained from the germ-free breeding colony of the department. Twice a month the germ-free status of the animals was monitored by the method described by Kunstyr (Kunstyr, 1992). The animals were maintained in positive-pressure isolators (Metall \& Plastik, Radolfzell, Germany) and housed in polycarbonate cages on irradiated wood chips at $22^{\circ} \mathrm{C}+/-2$ a relative air humidity of $55 \%+/-5$ on a 12 $\mathrm{h}$ light-dark cycle. They had free access to irradiated diet (Altromin fortified type 1314; Altromin, Lage, Germany) and autoclaved distilled water. Coprophagy was not prevented. Six-week-old male animals from each strain with a bodyweight of $205 \mathrm{~g} \pm 24$ were associated with human fecal microbiota via intragastric application of 1 $\mathrm{ml}$ of a 50 -fold diluted fecal sample. Human feces was collected from a healthy 30-year-old female volunteer, consuming a normal Western diet who had not taken antibiotics for at least one year prior to the study. The dilution of the fresh fecal sample with $0.9 \% \mathrm{NaCl}$ was done under anoxic conditions. The germ-free status of the rats was confirmed before association by the method described by Kunstyr (Kunstyr, 1992). After three and 12 months, six animals of each strain were killed by $\mathrm{CO}_{2}$ asphyxiation. The cecal contents were removed under sterile conditions and kept frozen at $-80^{\circ} \mathrm{C}$ until analysis. For comparison, six germ-free male Fischer 344 / Rehbruecke rats were conventionalized by association with the fecal bacteria from a specific pathogen-free (SPF) rat using the same procedure as described above for the human feces. They were maintained under the same conditions as described above, but outside the isolator in separate cages, in the same room as other SPF rats. During the first month of the experimental period, fecal samples from six animals of each rat strain were taken directly from the anus every other day. In the following two months, fecal samples were collected once a week, while the fecal samples from the remaining 12 animals were taken once a month. All samples were stored at $-80^{\circ} \mathrm{C}$ until further processing. The protocol for the animal experiment was approved by the Ministry of Nutrition, Agriculture and Forestry, Brandenburg, Germany.

\section{DNA extraction}

For DNA extraction $100 \mathrm{mg}$ (wet weight) of either fresh feces or cecal content was used. DNA extraction was performed following the protocol number five of the InViTek DNA isolation Kit III (InViTec, Berlin, Germany). The obtained DNA was dissolved in $100 \mu$ l elution buffer of the DNA isolation kit.

\section{PCR amplification for DGGE}

Primers U968-GC-f [5'-CGC CCG GGG CGC GCC CCG GGC GGG GCG GGG GCA CGG GGG GAA CGC GAA GAA CCT TAC-3'] and L1401-r [5'-CGG TGT GTA CAA GAC CC-3'] were used to amplify the $V 6$ to $V 8$ regions of the bacterial 16S rRNA gene (Nubel et al., 1996). Nucleotides comprising the "G+C-clamp" are underlined. PCRs were performed with a Taq polymerase kit from Invitrogen (Karlsruhe, Germany). PCR mixtures of $50 \mu \mathrm{l}$ total volume contained $0.25 \mathrm{mM}$ of each deoxy- 


\begin{tabular}{|c|c|c|c|c|c|c|c|c|c|c|c|c|c|c|c|}
\hline & 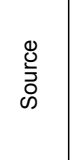 & 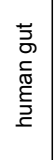 & 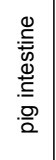 & 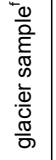 & 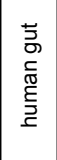 & 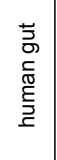 & 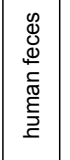 & 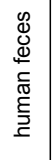 & 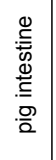 & 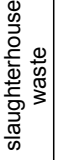 & $\stackrel{\oplus}{\check{c}}$ & 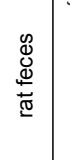 & 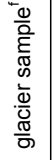 & $\begin{array}{l}\overline{\bar{\sigma}} \\
\underline{\underline{\underline{z}}} \\
\end{array}$ & \\
\hline & 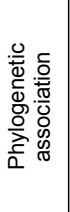 & 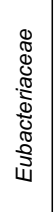 & 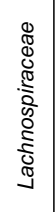 & 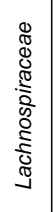 & 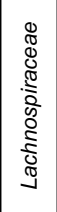 & 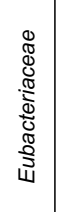 & 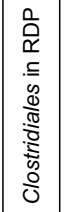 & 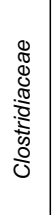 & 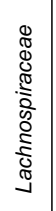 & 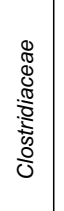 & 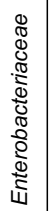 & 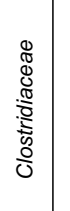 & 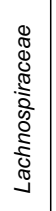 & 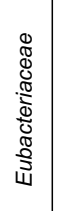 & \\
\hline & 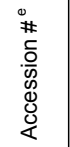 & 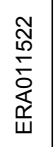 & $\begin{array}{l}0 \\
0 \\
o \\
\Xi\end{array}$ & 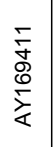 & 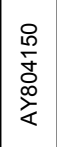 & 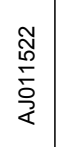 & . & 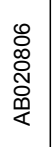 & $\begin{array}{l}0 \\
\stackrel{0}{o} \\
\stackrel{0}{\Xi}\end{array}$ & 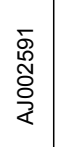 & 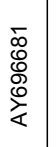 & 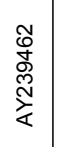 & 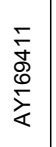 & 兽 & \\
\hline & 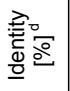 & के & $\stackrel{\infty}{\infty}$ & $\begin{array}{l}\infty \\
\infty\end{array}$ & ๕ & 8 & ठ & б. & $\infty$ & ৪ & б̆ & ৪ & Ф & ৪ & \\
\hline & 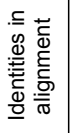 & 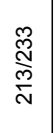 & $\begin{array}{l}\overline{\bar{p}} \\
\bar{m} \\
\bar{\rho} \\
\bar{m}\end{array}$ & $\begin{array}{l}\stackrel{P}{\mathbb{N}} \\
\stackrel{N}{N}\end{array}$ & $\begin{array}{l}\text { 芯 } \\
\text { 怘 } \\
\text { o. }\end{array}$ & 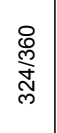 & 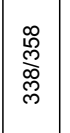 & 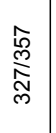 & $\begin{array}{l}\overline{\overline{0}} \\
\bar{m} \\
\bar{\phi}\end{array}$ & 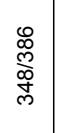 & 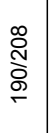 & 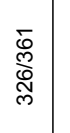 & 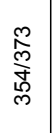 & 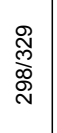 & \\
\hline & 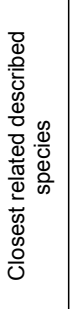 & 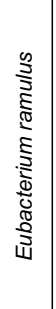 & 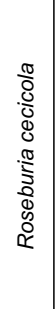 & 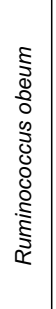 & 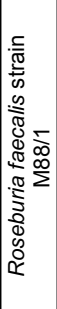 & 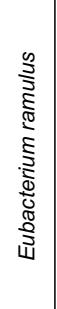 & 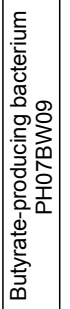 & 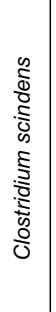 & 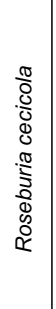 & 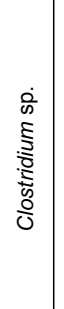 & 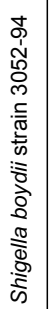 & 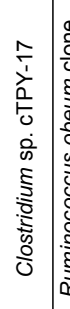 & 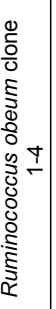 & 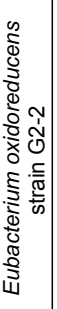 & ণิ \\
\hline & 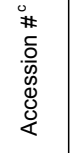 & 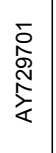 & 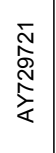 & $\begin{array}{l}\text { : } \\
\text { : } \\
\stackrel{N}{\grave{<}}\end{array}$ & $\begin{array}{l}\stackrel{\infty}{N} \\
\text { N } \\
\stackrel{N}{<} \\
\dot{<}\end{array}$ & 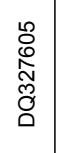 & 离 & 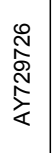 & $\begin{array}{l}\underset{N}{\hat{N}} \\
\stackrel{N}{\Sigma} \\
\stackrel{\Sigma}{<}\end{array}$ & 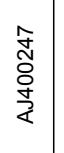 & 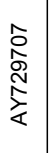 & 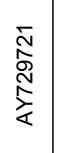 & 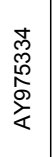 & 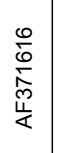 & 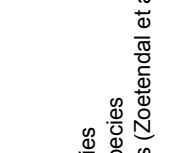 \\
\hline 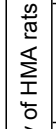 & 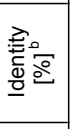 & $\tilde{\sigma}$ & ๕ & $\infty$ & $\mathscr{8}$ & $\delta$ & \& & б. & $\stackrel{\circ}{\circ}$ & ৪ & హ) & 边 & ๕ & ৪ & 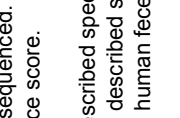 \\
\hline 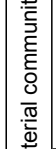 & 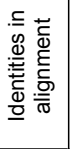 & 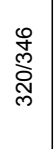 & 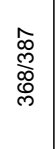 & 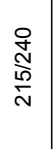 & 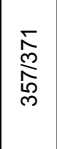 & 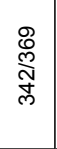 & $\begin{array}{l}\text { d } \\
0 \\
0 \\
0 \\
c \\
c\end{array}$ & 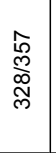 & 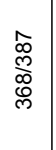 & 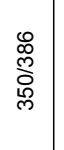 & 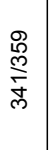 & 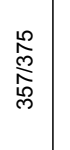 & 趈 & 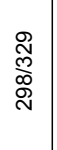 & 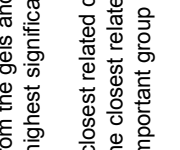 \\
\hline 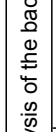 & 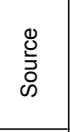 & 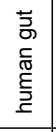 & 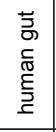 & 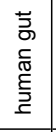 & 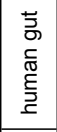 & 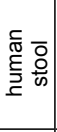 & 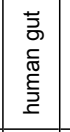 & 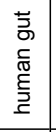 & 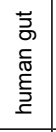 & 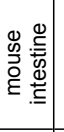 & 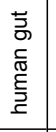 & 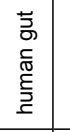 & 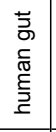 & . & 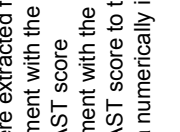 \\
\hline 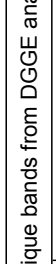 & 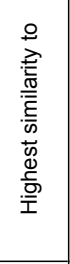 & 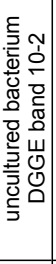 & 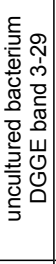 & 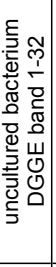 & 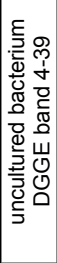 & 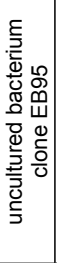 & 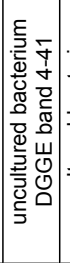 & 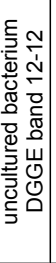 & 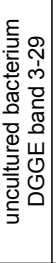 & 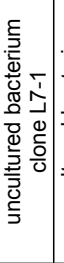 & 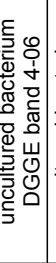 & 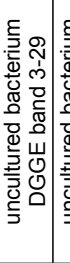 & 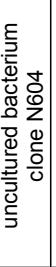 & 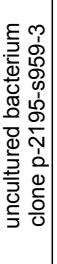 & 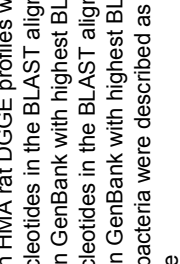 \\
\hline 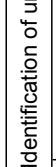 & 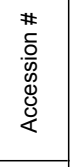 & 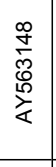 & 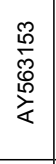 & 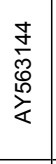 & 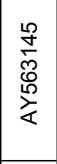 & 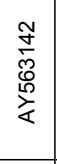 & 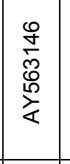 & 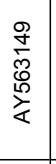 & 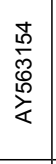 & 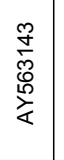 & 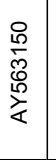 & 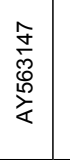 & 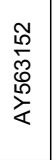 & 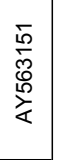 & 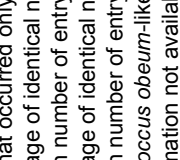 \\
\hline 卷 & 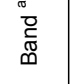 & $\ll$ & $\infty$ & 0 & 0 & ш & ५ & 0 & $I$ & - & $x$ & $\Sigma$ & z & 0 & $\$$ \\
\hline
\end{tabular}


nucleoside triphosphate, $2.5 \mathrm{U}$ Taq polymerase, $0.25 \mu \mathrm{M}$ of each primer and $1 \mu \mathrm{l}$ fecal DNA. PCR amplification was performed with a PCR thermo cycler (Hybaid, Heidelberg, Germany) under the following conditions: denaturation at $94^{\circ} \mathrm{C}$ for $5 \mathrm{~min}$, followed by a touch-down PCR starting with denaturation at $94^{\circ} \mathrm{C}$ for $30 \mathrm{sec}$, annealing at $66^{\circ} \mathrm{C}$ for $20 \mathrm{sec}$ and extension at $68^{\circ} \mathrm{C}$ for $40 \mathrm{sec}$. The annealing temperature was reduced by $1^{\circ} \mathrm{C}$ every fourth step until an annealing temperature of $59^{\circ} \mathrm{C}$ was reached followed by 14 additional cycles at this temperature. After completion, an extension step was performed at $68^{\circ} \mathrm{C}$ for $7 \mathrm{~min}$, and the samples were then cooled to $4^{\circ} \mathrm{C}$. Touch-down PCR was performed in order to reduce the formation of byproducts and to increase the specificity of the amplification. All PCR products were analyzed by electrophoresis in 1\% agarose gels and the amount of PCR products was estimated by comparison with a low DNA mass ladder (Invitrogen, Karlsruhe, Germany) before performing DGGE analysis.

\section{Analysis of $P C R$ products by DGGE}

PCR products (approximately 100 ng DNA per lane) were separated by DGGE as described by Muyzer et al. (Muyzer et al., 1993) using the Decode system (BioRad Laboratories, Hercules, California), with the following modifications: Polyacrylamide gels (dimensions, $200 \times$ $200 \times 0.8 \mathrm{~mm})$ consisted of $8 \%(\mathrm{v} / \mathrm{v})$ polyacrylamide (37.5:1 acrylamide-bisacrylamide, Merck, Darmstadt, Germany) and $0.5 \times$ Tris-acetate-EDTA (TAE, pH 8.3) buffer (Sambrook et al., 1989). A 100\% denaturing acrylamide solution contained $7 \mathrm{M}$ urea and $40 \%$ formamide. For separation of generated amplicons a gradient of 40 to $55 \%$ was used. The gels were poured from top using a gradient former and a pump (Econopump, BioRad Laboratories) at a speed of 9 $\mathrm{ml} / \mathrm{min}$. Before polymerization of the denaturing gel $(20$ $\mathrm{ml}$ gradient volume) a 7-ml stacking gel without denaturing agents was added, and an appropriate comb was inserted. Electrophoresis was performed at a constant temperature of $60^{\circ} \mathrm{C}$ for $10 \mathrm{~min}$ at $200 \mathrm{~V}$ and subsequently for $16 \mathrm{~h}$ at $85 \mathrm{~V}$ in $1 \times \mathrm{TAE}$ buffer $\mathrm{pH} 8.3$. Gels were stained with $\mathrm{AgNO} 3$ as described by Sanguinetti et al. (Sanguinetti et al., 1994) with the following modifications: The developing solution contained $1.5 \% \mathrm{NaOH}$ and $1.8 \%$ formaldehyde. The gels were stained for $10 \mathrm{~min}$ in $0.8 \% \mathrm{AgNO} 3$ and washed twice with distilled water for five minutes. After fixation, the gels were placed in a storage solution containing $25 \%$ ethanol and $10 \%$ glycerol in water for $7 \mathrm{~min}$. The gels were scanned using the white-light function of the "Chemi Doc" gel imaging system (BioRad Laboratories) and analyzed using the "Quantity One" software version 4.3.1 (BioRad Laboratories). The number of bands analyzed on a given gel varied between 30 and 50 . Each sample was compared with every other sample, and the Dice similarity coefficient was automatically determined using the similarity matrix function of the "Quantity one" software.

\section{Reproducibility of the method}

To investigate the reproducibility of the PCR-DGGE method the DNA from three different HMA rat fecal samples and one human donor fecal sample was prepared once and analyzed by six PCR-DGGE runs each, and the mean $\mathrm{C}_{\mathrm{s}}$ and the standard deviation (SD) for each sample were calculated.

\section{Sequencing of PCR-DGGE bands}

Bands that occurred exclusively in the DGGE profiles of HMA rats were excised from the gel, and the DNA was extracted, amplified and sequenced. One hundred microliter buffer $(10 \mathrm{mM}$ Tris $\mathrm{HCl}, 50 \mathrm{~mm} \mathrm{KCl}, 1.5 \mathrm{mM}$ $\mathrm{MgCl}_{2}$ and $0.1 \%$ Triton $\mathrm{X}-100, \mathrm{pH} 9$ ) was added to the excised bands (Sanguinetti et al., 1994). They were frozen in liquid nitrogen, defrosted at $50^{\circ} \mathrm{C}$, shaken for $20 \mathrm{~min}$ at $95^{\circ} \mathrm{C}$ and subsequently overnight at $37^{\circ} \mathrm{C}$. The DNA obtained from the excised bands was re-amplified with the primer 968f [5'-GAA CGC GAA GAA CCT TAC3'] without the "GC-clamp" and the primer 1378r [5'-CGG TGT GTA CAA GGC CCG GGA ACG-3'] [A. Fischer, personal communication] using the Taq polymerase kit from Invitrogen. PCR mixtures of $50 \mu \mathrm{l}$ contained $0.25 \mathrm{mM}$ of each deoxynucleoside triphosphate, $2.5 \cup$ Taq polymerase, $0.25 \mu \mathrm{M}$ of each primer and $5 \mu \mathrm{l}$ of the DNA solution. PCR amplification was performed under the following conditions: denaturation at $94^{\circ} \mathrm{C}$ for $5 \mathrm{~min}$, followed by 30 cycles of denaturation at $94^{\circ} \mathrm{C}$ for $45 \mathrm{~s}$, annealing at $60^{\circ} \mathrm{C}$ for 60 $\mathrm{s}$, and extension at $72^{\circ} \mathrm{C}$ for $1.5 \mathrm{~min}$. After completion, an additional extension step was performed at $72^{\circ} \mathrm{C}$ for 3 min and the samples were cooled to $4^{\circ} \mathrm{C}$. The PCR fragments were purified using the Roche high pure PCR products purification kit (Roche, Lörrach, Germany) and subjected to sequencing using the Amersham Bioscience DYEnamic ET Dye Terminator Cycle Sequencing Kit for MegaBACE DNA Analysis Systems (Amersham Biosciences, Freiburg, Germany) according to the manufacturers' instructions. The sequences were automatically analyzed on a capillary sequencer (MegaBace1000, Amersham Biosciences) and corrected manually. All sequences were checked for chimeras using "Chimera-Check" of the Ribosomal Database Project (Maidak et al., 1997). For identification of the most closely related described species underlying the partial 16S rRNA sequences, a search of the GenBank DNA database was conducted using the BLAST algorithm (Altschul et al., 1990).

\section{Statistical analysis}

The $\mathrm{C}_{\mathrm{s}}$ values comparing rat and the human microbiota are given as the means $+/-$ SD for each time point of the observation period. Differences between the means of all groups (the two HMA rat strains, conventional rats and the repetition of the human sample) were checked for significance. The significance was determined by means of an ANOVA and is indicated as $p<0.05$.

\section{Nucleotide sequence accession numbers}

Sequences determined in this study were deposited in the GenBank database under accession numbers AY563142 to AY563154.

\section{Acknowledgments}

We thank Martin Osterhoff for sequence analysis and Ines Grüner, Ute Lehmann and Renate Herzog for taking care of the animals.

\section{References}

Altschul, S. F., Gish, W., Miller, W., Myers, E. W., and Lipman, D. J. (1990). Basic local alignment search tool. J Mol Biol 215, 403-410.

ben Omar, N., and Ampe, F. (2000). Microbial community dynamics during production of the 
Mexican fermented maize dough pozol. Appl Environ Microbiol 66, 3664-3673.

Djouzi, Z., Andrieux, C., Degivry, M. C., Bouley, C., and Szylit, O. (1997). The association of yogurt starters with Lactobacillus casei DN 114.001 in fermented milk alters the composition and metabolism of intestinal microflora in germ-free rats and in human floraassociated rats. J Nutr 127, 2260-2266.

Edwards, C. A., Rumney, C., Davies, M., Parrett, A. M., Dore, J., Martin, F., Schmitt, J., Stahl, B., Norin, E., Midtvedt, T., et al. (2003). A human flora-associated rat model of the breast-fed infant gut. J Pediatr Gastroenterol Nutr 37, 168-177.

Gafan, G. P., and Spratt, D. A. (2005). Denaturing gradient gel electrophoresis gel expansion (DGGEGE)--an attempt to resolve the limitations of co-migration in the DGGE of complex polymicrobial communities. FEMS Microbiol Lett 253, 303-307.

Gerard, P., Beguet, F., Lepercq, P., Rigottier-Gois, L., Rochet, V., Andrieux, C., and Juste, C. (2004). Gnotobiotic rats harboring human intestinal microbiota as a model for studying cholesterol-to-coprostanol conversion. FEMS Microbiology Ecology 47, 337-343.

Hambly, R. J., Rumney, C. J., Cunninghame, M., Fletcher, J. M., Rijken, P. J., and Rowland, I. R. (1997a). Influence of diets containing high and low risk factors for colon cancer on early stages of carcinogenesis in human flora-associated (HFA) rats. Carcinogenesis 18, 1535-1539.

Hambly, R. J., Rumney, C. J., Fletcher, J. M., Rijken, P. J., and Rowland, I. R. (1997b). Effects of high- and low-risk diets on gut microflora-associated biomarkers of colon cancer in human flora-associated rats. Nutr Cancer 27, 250-255.

Hazenberg, M. P., Bakker, M., and Verschoor-Burggraaf, A. (1981). Effects of the human intestinal flora on germ-free mice. J Appl Bacteriol 50, 95-106.

Hirayama, K., Kawamura, S., and Mitsuoka, T. (1991). Development and Stability of Human Faecal Flora in the Intestine of Ex-germ-free Mice. Microb Ecol Health D 4, 95-99.

Hirayama, K., Miyaji, K., Kawamura, S., Itoh, K., Takahashi, E., and Mitsuoka, T. (1995). Development of intestinal flora of human-flora-associated (HFA) mice in the intestine of their offspring. Exp Anim 44, 219-222.

Kamlage, B., Hartmann, L., Gruhl, B., and Blaut, M. (1999). Intestinal microorganisms do not supply associated gnotobiotic rats with conjugated linoleic acid. J Nutr 129, 2212-2217.

Kassie, F., Rabot, S., Kundi, M., Chabicovsky, M., Qin, H. M., and Knasmuller, S. (2001). Intestinal microflora plays a crucial role in the genotoxicity of the cooked food mutagen 2-amino-3-methylimidazo [4,5f]quinoline. Carcinogenesis 22, 1721-1725.

Kibe, R., Sakamoto, M., Yokota, H., Ishikawa, H., Aiba, Y., Koga, Y., and Benno, Y. (2005). Movement and fixation of intestinal microbiota after administration of human feces to germfree mice. Appl Environ Microbiol 71, 3171-3178.

Kunstyr, I. (1992). Investigation of germ-free animals. In Diagnostic Microbiology for Laboratory Animals, I. Kunstyr, ed. (Stuttgart, Jena, New York, Gustav Fischer Verlag), pp. 42-44.

Maidak, B. L., Olsen, G. J., Larsen, N., Overbeek, R., McCaughey, M. J., and Woese, C. R. (1997). The RDP (Ribosomal Database Project). Nucleic Acids Res 25, 109-111.

Mallett, A. K., Bearne, C. A., Rowland, I. R., Farthing, M. J., Cole, C. B., and Fuller, R. (1987). The use of rats associated with a human faecal flora as a model for studying the effects of diet on the human gut microflora. J Appl Bacteriol 63, 39-45.

Marteau, P., Pochart, P., Dore, J., Bera-Maillet, C., Bernalier, A., and Corthier, G. (2001). Comparative study of bacterial groups within the human cecal and fecal microbiota. Appl Environ Microbiol 67, 49394942.

Muyzer, G. (1999). DGGE/TGGE a method for identifying genes from natural ecosystems. Curr Opin Microbiol 2, 317-322.

Muyzer, G., de Waal, E. C., and Uitterlinden, A. G. (1993). Profiling of complex microbial populations by denaturing gradient gel electrophoresis analysis of polymerase chain reaction-amplified genes coding for 16S rRNA. Appl Environ Microbiol 59, 695-700.

Nubel, U., Engelen, B., Felske, A., Snaidr, J., Wieshuber, A., Amann, R. I., Ludwig, W., and Backhaus, H. (1996). Sequence heterogeneities of genes encoding 16S rRNAs in Paenibacillus polymyxa detected by temperature gradient gel electrophoresis. J Bacteriol 178, 5636-5643.

Qiu, X., Wu, L., Huang, H., McDonel, P. E., Palumbo, A. V., Tiedje, J. M., and Zhou, J. (2001). Evaluation of PCR-generated chimeras, mutations, and heteroduplexes with $16 \mathrm{~S}$ rRNA gene-based cloning. Appl Environ Microbiol 67, 880-887.

Raibaud, P., Ducluzeau, R., Dubos, F., Hudault, S., Bewa, H., and Muller, M. C. (1980). Implantation of bacteria from the digestive tract of man and various animals into gnotobiotic mice. Am J Clin Nutr 33, 2440-2447.

Rowland, I. R., Mallett, A. K., Bearne, C. A., and Farthing, M. J. (1986). Enzyme activities of the hindgut microflora of laboratory animals and man. Xenobiotica 16, 519-523.

Rumney, C. J., and Rowland, I. R. (1992). In vivo and in vitro models of the human colonic flora. Crit Rev Food Sci Nutr 31, 299-331.

Rumney, C. J., Rowland, I. R., and O'Neill, I. K. (1993). Conversion of IQ to 7-OHIQ by gut microflora. Nutr Cancer 19, 67-76.

Sambrook, J., Fritsch, E. F., and Maniatis, T. (1989). Molecular cloning, a laboratory manual, $2 \mathrm{n}$ ed. edn (Cold Spring Harbor, NY, Cold Spring Harbor Laboratory).

Sanguinetti, C. J., Dias Neto, E., and Simpson, A. J. (1994). Rapid silver staining and recovery of PCR products separated on polyacrylamide gels. Biotechniques 17, 914-921.

Satokari, R. M., Vaughan, E. E., Akkermans, A. D., Saarela, M., and de Vos, W. M. (2001). Bifidobacterial diversity in human feces detected by genus-specific PCR and denaturing gradient gel electrophoresis. Appl Environ Microbiol 67, 504-513.

Schwiertz, A., Gruhl, B., Lobnitz, M., Michel, P., Radke, M., and Blaut, M. (2003). Development of the intestinal bacterial composition in hospitalized preterm infants in comparison with breast-fed, full-term infants. Pediatr Res 54, 393-399.

Stackebrandt, E., and Goebel, B. (1994). Taxonomic note: a place for DNA-DNA reassociation and $16 \mathrm{~S}$ rRNA sequence analysis in the present species definition in bacteriology. Int J Syst Bacteriol 44, 846849.

Suau, A., Bonnet, R., Sutren, M., Godon, J. J., Gibson, G. R., Collins, M. D., and Dore, J. (1999). Direct analysis of genes encoding $16 \mathrm{~S}$ rRNA from complex communities reveals many novel molecular species 
within the human gut. Appl Environ Microbiol 65, 4799-4807.

Suzuki, M. T., and Giovannoni, S. J. (1996). Bias caused by template annealing in the amplification of mixtures of $16 \mathrm{~S}$ rRNA genes by PCR. Appl Environ Microbiol 62, 625-630.

Vaughan, E. E., Schut, F., Heilig, H. G., Zoetendal, E. G., de Vos, W. M., and Akkermans, A. D. (2000). A molecular view of the intestinal ecosystem. Curr Issues Intest Microbiol 1, 1-12.

Wintzingerode, F. v., Gobel, U. B., and Stackebrandt, E. (1997). Determination of microbial diversity in environmental samples: pitfalls of PCR-based rRNA analysis. FEMS Microbiology Reviews 21, 213-229.

Zoetendal, E. G., Akkermans, A. D., and De Vos, W. M. (1998). Temperature gradient gel electrophoresis analysis of 16S rRNA from human fecal samples reveals stable and host-specific communities of active bacteria. Appl Environ Microbiol 64, 3854-3859.

Zoetendal, E. G., Akkermans, A. D. L., Akkermans vanVliet, W. M., de Visser, J. A. G. M., and de Vos, W. M. (2001). The host genotype affects the bacterial community in the human gastrointestinal tract. Microbial Ecol Health Dis 13, 129-134.

Zoetendal, E. G., Ben-Amor, K., Harmsen, H. J., Schut, F., Akkermans, A. D., and de Vos, W. M. (2002). Quantification of uncultured Ruminococcus obeumlike bacteria in human fecal samples by fluorescent in situ hybridization and flow cytometry using $16 \mathrm{~S}$ rRNAtargeted probes. Appl Environ Microbiol 68, 42254232. 


\section{Further Reading}

Caister Academic Press is a leading academic publisher of advanced texts in microbiology, molecular biology and medical research. Full details of all our publications at caister.com

- MALDI-TOF Mass Spectrometry in Microbiology Edited by: M Kostrzewa, S Schubert (2016) www.caister.com/malditof

- Aspergillus and Penicillium in the Post-genomic Era Edited by: RP Vries, IB Gelber, MR Andersen (2016) www.caister.com/aspergillus2

- The Bacteriocins: Current Knowledge and Future Prospects Edited by: RL Dorit, SM Roy, MA Riley (2016)

www.caister.com/bacteriocins

- Omics in Plant Disease Resistance Edited by: V Bhadauria (2016) www.caister.com/opd

- Acidophiles: Life in Extremely Acidic Environments Edited by: R Quatrini, DB Johnson (2016) www.caister.com/acidophiles

- Climate Change and Microbial Ecology: Current Research and Future Trend

Edited by: J Marxsen (2016)

www.caister.com/climate

- Biofilms in Bioremediation: Current Research and Emerging Technologies

Edited by: G Lear (2016)

www.caister.com/biorem

- Microalgae: Current Research and Applications Edited by: MN Tsaloglou (2016) www.caister.com/microalgae

- Gas Plasma Sterilization in Microbiology: Theory, Applications, Pitfalls and New Perspectives Edited by: H Shintani, A Sakudo (2016) www.caister.com/gasplasma

- Virus Evolution: Current Research and Future Directions Edited by: SC Weaver, M Denison, M Roossinck, et al. (2016) www.caister.com/virusevol

- Arboviruses: Molecular Biology, Evolution and Control Edited by: N Vasilakis, DJ Gubler (2016) www.caister.com/arbo

- Shigella: Molecular and Cellular Biology Edited by: WD Picking, WL Picking (2016) www.caister.com/shigella

-Aquatic Biofilms: Ecology, Water Quality and Wastewater Treatment

Edited by: AM Romaní, H Guasch, MD Balaguer (2016)

www.caister.com/aquaticbiofilms

- Alphaviruses: Current Biology

Edited by: S Mahalingam, L Herrero, B Herring (2016)

www.caister.com/alpha

- Thermophilic Microorganisms

Edited by: F Li (2015)

www.caister.com/thermophile
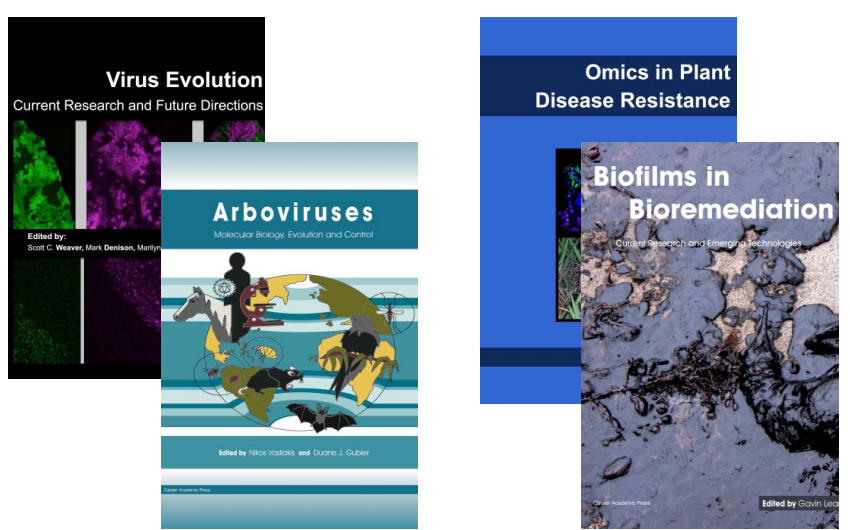
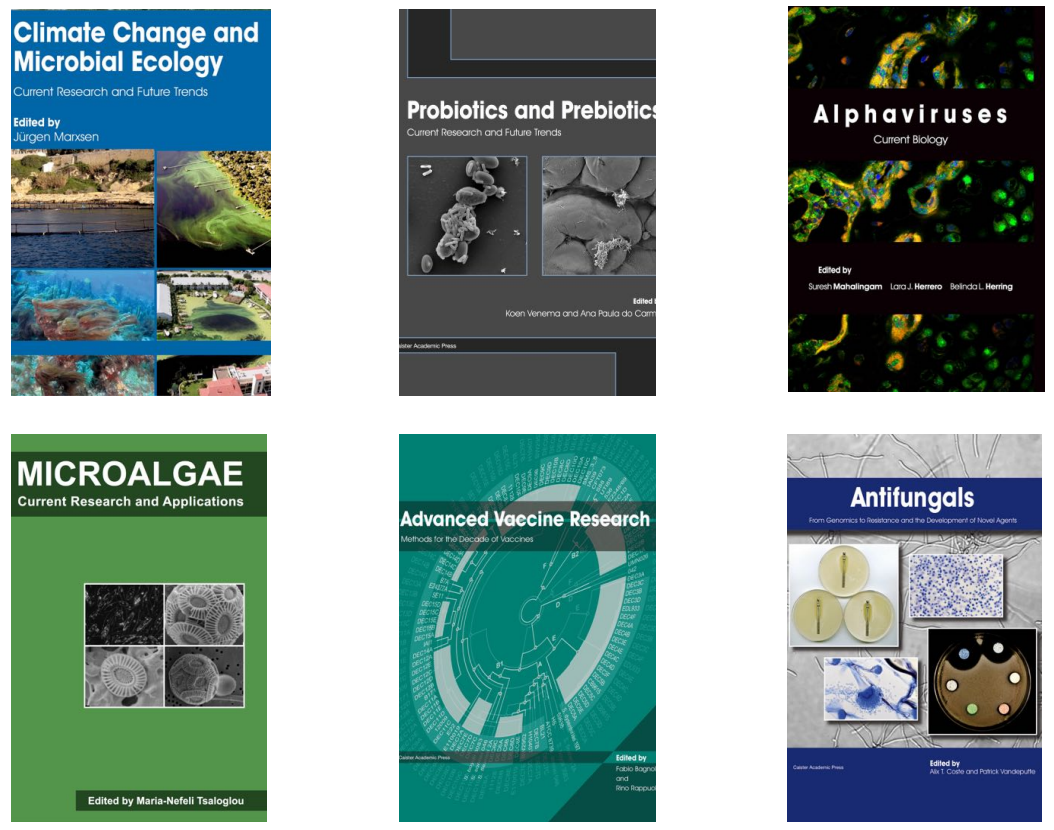

- Flow Cytometry in Microbiology: Technology and Applications Edited by: MG Wilkinson (2015) www.caister.com/flow

- Probiotics and Prebiotics: Current Research and Future Trends Edited by: K Venema, AP Carmo (2015) www.caister.com/probiotics

- Epigenetics: Current Research and Emerging Trends Edited by: BP Chadwick (2015) www.caister.com/epigenetics2015

- Corynebacterium glutamicum: From Systems Biology to Biotechnological Applications

Edited by: A Burkovski (2015)

www.caister.com/cory2

- Advanced Vaccine Research Methods for the Decade of Vaccines

Edited by: F Bagnoli, R Rappuoli (2015)

www.caister.com/vaccines

- Antifungals: From Genomics to Resistance and the Development of Novel Agents

Edited by: AT Coste, P Vandeputte (2015)

www.caister.com/antifungals

- Bacteria-Plant Interactions: Advanced Research and Future Trends Edited by: J Murillo, BA Vinatzer, RW Jackson, et al. (2015) www.caister.com/bacteria-plant

\section{- Aeromonas}

Edited by: J Graf (2015)

www.caister.com/aeromonas

- Antibiotics: Current Innovations and Future Trends

Edited by: S Sánchez, AL Demain (2015)

www.caister.com/antibiotics

- Leishmania: Current Biology and Contro Edited by: S Adak, R Datta (2015) www.caister.com/leish2

- Acanthamoeba: Biology and Pathogenesis (2nd edition) Author: NA Khan (2015)

www.caister.com/acanthamoeba2

- Microarrays: Current Technology, Innovations and Applications Edited by: Z He (2014)

www.caister.com/microarrays2

- Metagenomics of the Microbial Nitrogen Cycle: Theory, Methods and Applications

Edited by: D Marco (2014)

www.caister.com/n2 